\title{
出身大学の学校歴と専攻分野が初職に与える 影響の男女比較分析
}

—学校歴効果の限定性と専攻間トラッキング——

\section{豊永 耕平*}

本稿では, 出身大学の学校歴と専攻分野が初職にもたらす影響の男女比較分 析を行った．高等教育の大衆化の中で大卒学歴内部の相対的な格差は拡大傾向 にあるが, 既存研究では大卒男性の学校歴に着目した研究が蓄積されてきた一 方で, 専攻分野や出身階層に着目した研究はほとんど蓄積されておらず, 大卒 女性も分析対象から除外されてきた. SSM1995 年調查, 2005 年調查, 2015 年 調查の合併デー夕を用いて尃攻分野, 出身階層, 大卒女性も含めた分析を行っ た結果, 以下の 3 点が示された. 第 1 に, 学校歴は訓練可能性のシグナルとし て初職の企業規模を左右する一方, 専攻分野もまた職場で応用可能な能力のシ グナルとして専門職入職に影響していた，第 2 に, 出身階層の初職への影響は, 学校歴というよりも専攻分野が大きく媒介しており，世代間移動を説明するの に将来的な職業達成を見通した専攻分野選択とその階層差が重要な役割を果た していた，第 3 に, 専攻分野が初職にもたらす影響にはジェンダー差があり, 人文系出身者の初職での不利は男性に限定的である一方で, 同じ理工系出身で も女性は男性ほど事務販売職と比べて専門職になりやすいわけではなかった. 以上から, 学校歴が大きく影響するのは企業規模であるという限定性があるの に対して，一見すると自由な教育選択による専攻間トラッキングもまた出身階 層や男女間の差異を伴って重要な役割を果たしていることが示された.

キーワード: 学校歴, 専攻分野, 初職

\section{1 問 題 設 定}

大学進学率は, 近年では $52.6 \%$ （男性 55.9\%, 女性 49.1\%）にも達しており $\left(\right.$ 文部科学省 2017) ${ }^{1)}$, 仮に同じ「大卒学歴」であっても, 職業達成や収入面では 一枚岩ではないことがよく知られている (平沢 2011)。こうした大卒学歴内部の格 差は，高学歴化を経験した多くの国で報告されており（Gerber \& Cheung 2008）， なぜ同じ教育年数(同じ人的資本の蓄積) の中で相対的な違いが生まれるのかを検 証することが国際的にも重要な課題とされてきた.

* 東京大学大学院教育学研究科・日本学術振興会 kohei.toyonaga@gmail.com 
しかしながら, 大卒学歴内部に着目した既存研究には, 以下のような解決すべき 課題がある. 第 1 に, 学校歷（出身大学）がその後のキャリアに与える影響につい ては研究が蓄積されてきた一方で, 専攻分野（出身学部）が果たす役割がほとんど 検討されていないことである. 専攻分野の違いは，大学の専門教育を通じて獲得し たスキルの違いを意味し，雇用主も職場で応用可能なスキルの指標として評価する (Di Stasio \& van de Werfhorst 2016). そのため専攻分野も重要な役割を果たして いるはずであり，その位置づけを議論する必要がある.

解決すべき課題の第 2 は，大卒者の世代間移動がほとんど検討されていないこと である．欧米諸国では，高等教育が大衆化しても特権的集団は質的に有利な選択肢 を探し出すために全体の不平等が維持されることが重要な課題とされており (Lucas 2017), 将来的な職業達成を見通した専攻分野の選択に出身階層が影響する ことも議論されてきた（Kraaykamp et al. 2013）. 日本社会でも, 専攻分野の選択 は有利な選択肢を探し出す教育選択のひとつと考えられるため, こうした専攻分野 の選択が世代間移動をどの程度まで説明するのかを示す必要がある．しかしながら， 大卒者のサンプルサイズが小さいという課題もあってか, 既存研究では大学進学後 の出身階層の影響は十分に検討されておらず，学校歴や専攻分野を統制しても出身 階層の直接効果が残存するのかどうかも明らかにされてこなかった.

解決すべき課題の第 3 は，大卒女性に関する研究が十分に蓄積されていないこと である. 近年では, 4 年制大学に進学する女性が増加傾向にあり, 専攻分野選択の ジェンダー差も関心を集めている（河野 2009）。しかしながら，大卒者に占める女 性の比率があまり高くなかったこともあってか，大卒学歴内部に着目した既存研究 のほとんどで検討対象から女性は除外されてきた，そのため，専攻分野の選択に関 するジェンダー差は議論されても, 専攻分野がキャリアにもたらす影響自体にジェ ンダー差がある可能性は十分に議論されて抢らず，学校歴や専攻分野がもたらす影 響の男女間の相違も明らかにされてこなかった。

以上から本稿では, 出身大学の学校歴と専攻分野が初職に与える影響について男 女比較分析を行うことで，学校歴と専攻分野が日本社会で果たす役割を明らかにす る. 本稿の構成を説明する，2節では，大卒学歴内部に着目した国内外の先行研究 の整理を行うことで学校歴と専攻分野に着目する視座を獲得し, 本稿の位置づけと 仮説を議論する．３節でデー夕と変数を示した後，4節では全国無作為抽出デー夕 から学校歴と専攻分野が初職に与える影響の男女比較分析を行う． 5 節では, 分析 結果から本稿のまとめを行う.

\section{2 先行研究の整理}

\section{1 学校歴と専攻分野に関する既存研究の知見}

入試選抜度の違いによる学校間の序列構造が明暸な日本社会では, 出身大学の学 校歴は「どのような会社に入社するか」を左右するとされてきた（天野 2006）。雇 
用主は, 入社希望者の技能を直接は観察できないため, 訓練可能性の代理指標とし て学校歴を活用し,「いったんある大学から採用しなくなると次の年からその大学 からの応募者が激変するので，採用のとぎれがないようにする」（竹内 1995：139） ため, 長期的に学校歴と企業規模の関連が継続することになる.

こうした中で, 大卒学歴の内部に着目した既存研究では, 大卒男性の学校歴に着 目した分析が多くなされてきた，学校歴の出身階層差に関しては, 入試選抜難易度 の高い銘柄大学への進学には出身階層差が存在し, その関連が長期的には安定傾向 にある（尾嶋 1990）。さらに, 銘柄大学出身の男性は初職威信スコアが高い傾向に あり (平沢 2011), 高学歴化の中で, 銘柄大学出身の男性では現職威信スコアが高 い水準のまま安定傾向にある一方で, 非銘柄大学出身の男性では低下傾向にあるこ とも確認されている（Fujihara＆ Ishida 2016）。このように日本の既存研究では, 大卒男性に着目した分析から, 企業規模というょりも職種（威信スコア）と学校歴 の関連を検討する研究が多く蓄積されてきた ${ }^{2)}$.

その一方で欧米諸国の研究では, 専攻分野の違いに焦点をあてた研究が多く蓄積 されている (Kalmijn \& van der Lippe 1997 など). Di Stasio \& van de Werfhorst （2016）は，大学の専門教育は特定の職業や産業に通じる訓練機会としての㑯面も あるため, 特にオランダの雇用主は, 専攻分野の教育内容と職場での応用可能性を 重視していることを報告している33). D. Reimer et al. (2008) も，ヨーロッパ 22 カ 国中の 21 力国で人文系出身者の失業率が高いことを指摘し, 専攻分野がその後の キャリアに与える影響の大きさを明らかにしている. 人文系などの専門教育は, 特 定の職業・技能との結びつきが弱いこともあって, ネガティブな評価・影響を受け やすいとされる (Ortiz \& Rodriguez-Menés 2016).

こうした, 専攻分野がその後のキャリアにもたらす影響を背景にして, 専攻分野 選択の階層差と, 世代間移動での役割もまた重要な研究課題とされてきた（Gerber \& Cheung 2008). H. G. van de Werfhorst \& R. Luijkx（2010）は，一見すると 自由な教育選択と想定される専攻分野選択には出身階層差があり, 将来的な職業達 成を見通した専攻分野の選択が世代間移動で重要な役割を果たしていることを明ら かにしている，そして専攻分野と出身階層の関連は高等教育の大衆化の中で強まっ ていることも報告されてきた (Kraaykamp et al. 2013).

以上のように, 高等教育の大衆化を背景にして大卒学歴内部に着目する必要性は 国内外の研究で見解が一致しているが, 中心的な分析視角は海外の研究では専攻分 野にある一方, 日本の研究では学校歴にあった. 近年では日本の研究でも専攻分野 が着目されつつあるが, 白川俊之（2015）が高校 2 年生の専攻分野の選択希望には 出身階層差があることを指摘している一方で, 大卒男性の分析を行った胡中孟徳 （2015）は専攻分野が世代間移動を十分に説明しないことを指摘しており，知見が 一致していない.さらに, 学校歴がキャリアに与える影響については男性に限定し て研究が蓄積されてきたが, 専攻分野が果たす役割は十分に検討されておらず, 女 性も含めてその位置づけが議論されてこなかった。 


\section{2 専攻分野とジェンダーに関する既存研究の知見}

その一方で, 専攻分野選択にジェンダーから着目した研究は多く蓄積されてきた ことは事実である．理工系の進路選択にはジェンダー差が大きく，学力とは独立し た性別規範が女性の専攻分野選択を水路づけているからである（河野 2009）。高松 里江（2014）は，高校生の専攻分野選択に対する多重対応分析の結果，性別の偏り に対応するジェンダートラック軸の存在を報告している．古田和久（2016）も，女 性は自らの理数系学力を低く評価しやすく, 男女比が同等な学校ほど理数系は男性 の領域とみなされやすいことを明らかにしている。

しかしながら，そもそも理工系に進学した女性が理工系出身の男性と同様の評価 を獲得できるのかは明らかではない点で依然として大きな課題が残されている（山 本・安井 2016). M. Kalmijn \& T. van der Lippe（1997）は，理工系出身女性は理 工系出身男性と同様の社会的な評価を得にくいことを明らかにし，女性が理工系に 進学しないことは合理的であることを指摘している. K. A. Shauman（2006）も, 労働市場が男女で分断されているために同じ専攻分野出身者であっても男女間で参 入する職域が異なり, 専攻分野選択だけでなく専攻分野がもたらす影響にもジェン ダー差が生まれることを報告している.

こうした議論を踏まえれば，日本の研究には専攻分野がその後のキャリアに与え る影響が不透明なまま，選択段階でのジェンダー差が議論されている問題がある.

高松（2008）は女性向き進路とされる人文系の出身者が現職で正規雇用になりにく いことを指摘している。 また山本耕平・安井大輔（2016）は，男性向き進路とされ る理工系の出身であることが女性にとってネガティブなシグナルになることを明ら かにしている. しかしながら, サンプルサイズの問題もあってか, いずれの研究で も男女間の比較分析は行われて㧍らず，専攻分野がもたらす影響のジェンダー差は 明らかにされていない，大卒男性に限定した研究が多く蓄積されていることを踏ま えれば，大卒女性にも着目した研究が必要である。

\section{3 本稿の位置づけと仮説の設定}

このように大卒学歴内部に着目した既存研究に押いては, 専攻分野や出身階層を 明示的に組み込んだ分析や，女性も対象に含めた分析がほとんど行われてこなかっ た．日本でも，訓練可能性を示す学校歴だけではなく，専攻分野もまた職場で応用 可能な能力のシグナルとして重要な役割を果たしているはずであり，専攻分野選択 の階層差も踏まえて検討する必要がある。また， 4 年制大学に進学する女性が増加 している現状を踏まえれば，大卒女性の検討は重要であり，専攻分野がもたらす影 響のジェンダー差も明らかにする必要がある。こうした目的を達成するために本稿 では，学校歴と専攻分野が初職に与える影響の男女比較分析を行い，以下のような 仮説を検証していく.

はじめに，学校歴と専攻分野に関する国内外での議論を踏まえれば，学校歴は訓 練可能性を示す能力のシグナルとして初職の企業規模を左右するが，専攻分野は特 
定の職業で応用可能な能力のシグナルとして専門職入職に影響することが推測され る. すなわち, 男女ともに入試選抜度の高い大学の出身者ほど初職の企業規模が大 きく, 社会科学系と比べて教育内容の専門性が高い理工系・医療系・教育系出身者 の方が事務販売職よりも専門職に入職しやすいだろう。常識的ではあるものの, 議 論の導入としてこれを【仮説 1】としたい.

つぎに，高等教育が大衆化しても特権的な集団は質的に有利な選択肢を探し出す という欧米諸国の議論を踏まえれば（Lucas 2017）, 日本においても, 教育選抜に 基づく学校歴ではなくて, 教育選択に基づく専攻分野が出身階層の初職への影響を 大きく媒介することが推測される，具体的には，男女ともに父職地位が尃門職の場 合には, 理工系や教育系などの専門職への入職が見通しやすい専攻分野を選択しや すいために，本人もまた事務販売職と比べて専門職に入職しやすいと考えられる.

これを【仮説 2】として検証することで，日本の既存研究では十分に検討されてこ なかった大学進学後の出身階層の影響と専攻分野選択の階層差を明らかにする.

最後に, 日本の労働市場は「一般職・総合職」といったコース別採用もあって初 職入職時から男女で異なるトラックに分断されており，そのため男女間格差も大き い（山口 2017）。こうした日本の労働市場の実情を踏まえれば，同じ「文系」とさ れるカテゴリーでも人文系出身男性は大企業に就職しにくいのに対して，女性の場 合には人文系と社会科学系出身者に大きな差がないかもしれない【仮説 3a】.とい うのも, 欧米諸国のように人文系専攻は職場での応用可能性が低いとネガティブな 評価を受けやすいとしても (Reimer et al. 2008), 女性の場合は「一般職」などで 長期勤続が期待されないため, 専攻分野にこだわらない採用が行われる可能性があ るからである。 その一方で, 同じ理工系出身でも女性は男性と同様の職域には入職 しにくいという欧米諸国での議論を踏まえれば（Shauman 2006），日本の労働市場 でも理工系進路で男女の職域分離が大きく, 理工系出身女性は男性ほど事務販売職 と比べて専門職になりやすいわけではないかもしれない【仮説 3b】.

\section{3 データと変数}

本稿で使用するデー夕は，「社会階層と社会移動全国調查」(SSM 調查）の 1995 年調查・2005 年調查・2 015 年調査の合併データである ${ }^{4)}$. 大卒男女の十分なサン プルを確保するために過去の調査データを合併して使用する. SSM 調査は, 回答 者の出身大学名に加えて, 出身学部も学科単位で詳細に訊ねているため, 本稿の問 題関心に合致する.

分析対象は, 初職入職前に新制大学を卒業した大卒男性（1,865 名）と大卒女性 (884 名) である. 本稿の問題関心は, 初職入職時に学校歴と専攻分野が訓練可能 性・応用可能性を示す能力のシグナルとして働くことが想定される被雇用者にある ため, 初職の従業上の地位が経営者と自営・家族従業者は除外し, 職種が農業の者 も分析から除外した．従属変数となる初職は職種だけではなく企業規模も考慮した 
表 1 記述統計量（值は該当パーセント，（）内は有効度数）

\begin{tabular}{|c|c|c|c|c|c|}
\hline 変数 & 男性 & 女性 & 変数 & 男性 & 女性 \\
\hline 本人初職 & & & 小企業 W & 12.68 & 12.05 \\
\hline 専門 & 35.72 & 43.68 & 自営 W & 8.47 & 7.26 \\
\hline 大企業 W & 36.27 & 34.12 & 大企業 B & 8.03 & 7.12 \\
\hline 小企業 W & $16.40^{(1817)}$ & $19.48^{(847)}$ & 小企業 B & $7.71(1570)$ & $6.71(730)$ \\
\hline ブルー & 11.61 & 2.72 & 自営 B & 8.15 & 7.53 \\
\hline SSM 調査年 & & & 農業 & 8.09 & 4.79 \\
\hline 1995 年調查 & 13.62 & 9.05 & 無職 + 父不在 & 4.46 & 3.84 \\
\hline 2005 年調査 & $33.30(1865)$ & $28.39(884)$ & 学歴 & & \\
\hline 2015 年調査 & 53.08 & 62.56 & 大学院修了 & $9.38(1865)$ & $6.45(884)$ \\
\hline 入職コーホート & & & 学校歴 & & \\
\hline 1969 年以前 & 17.88 & 4.98 & 国公立大学 $\mathrm{A}$ 群 & 8.78 & 3.40 \\
\hline 1970 年代 & 22.45 & 15.63 & 国公立大学B群 & 20.58 & 25.82 \\
\hline 1980 年代 & $23.25(1862)$ & $21.63(883)$ & 私立大学 $C$ 群 & $18.15(1686)$ & $9.57(794)$ \\
\hline 1990 年代 & 21.05 & 28.31 & 私立大学 $\mathrm{D}$ 群 & 27.11 & 25.94 \\
\hline 2000 年代以降 & 15.36 & 29.45 & 私立大学 $\mathrm{E}$ 群 & 25.39 & 35.26 \\
\hline 初職時の居住地 & & & 専攻分野 & & \\
\hline 大都市圈 & $63.33(1846)$ & $61.43(879)$ & 人文系専攻 & 6.49 & 32.00 \\
\hline 両親の学歴 & & & 社会科学系専攻 & 46.48 & 21.57 \\
\hline 両親非大卒 & 69.86 & 55.98 & 理工系専攻 & 34.43 & 7.15 \\
\hline 一方大卒 & $20.48(1626)$ & $26.63(811)$ & 医療系専攻 & $3.47^{(1818)}$ & $7.50^{(853)}$ \\
\hline 両親大卒 & 9.66 & 17.39 & 教育系専攻 & 6.38 & 16.88 \\
\hline 父職地位 & & & その他専攻 & 2.75 & 14.89 \\
\hline 専門 & 17.90 & 25.48 & 学校経由の就職 & & \\
\hline 大企業 W & $24.52^{(1570)}$ & $25.21^{(730)}$ & 学校経由あり & 42.08 (1787) & $36.36(858)$ \\
\hline
\end{tabular}

分析を行う目的から SSM 総合 8 分類を使用した. 専門, 大企業 W, 小企業 W, 大企業 $\mathrm{B}$ ，小企業 B が設定されることになるが，ブルーカラーになる割合は極め て低く，本稿の問題関心でもないため，多変量解析では結果の揭載を省略した。出 身階層は 15 歳時の父職地位を SSM 総合 8 分類に無職+父不在を加えて検討する.

本稿の分析で中心となる説明変数は学校歴と専攻分野である. 学校歴は, 設置時 期に着目した大学類型から（金子 1996）, 国公立大学 A 群, B 群, 私立大学 C 群, $\mathrm{D}$ 群， $\mathrm{E}$ 群を示すダミー変数として設定した。 国公立大学 $\mathrm{A}$ 群は, 旧帝国大学と 一橋大学・東京工業大学などの設置時期が古く社会的評価も高い国公立大学である. $\mathrm{B}$ 群は, 千葉大学や金沢大学などの $\mathrm{A}$ 群以外の国公立大学を指す. 私立大学 $\mathrm{C}$ 群 は，早稲田大学・関西大学などの設置時期が古く社会的評価も高い中核私立大学に 該当し, D 群は日本大学や中京大学などの 1960 年以前に設置された C 群以外の第 1 世代私立大学に該当する. E 群は城西大学や和光大学などの 1960 年以降に設置 された第 2 世代以後の新設私立大学を指す5).

中心となるもう 1 つの説明変数である専攻分野は, 学校基本調査の学科系統大分 類に準拠した専攻分野分類を使用した. ただし, 理学・農学は単独ではケース数が 
少ないため, 工学と統合して理工系というカテゴリーにした，また，同様のケース 数の問題から, 医学・薬学も医療系として統合し, 家政・商船・芸術も統合してそ の他専攻とした.

統制変数としては, SSM 調査年, 入職コーホート, 初職時の居住地が大都市圈 (宮城 - 首都圈 - 愛知 - 関西圈 - 福岡), 両親の学歴を投入し, 大学院修了経験と学 校経由の就職も統制している. 学校経由の就職は大企業や専門職へのアクセスを高 めることが報告されており（石田 2005）, 特に理工系では学校経由での就職が多い とされている（石田 2014）。本稿では, 就職方法の違いによらない尃攻分野の影響 を検証する目的から「卒業した学校の先輩（学校や先生）の紹介」を通じた就職を 学校経由の就職ととらえ, 就職方法の違いを統制するダミー変数として使用する. 分析に使用する変数の記述統計量を表 1 に示した.

\section{4 分 析}

\section{1 記述的分析}

はじめに専攻分野と初職の関連を男女別に示すと, 図 1 と図 2 のようになる。 こ うした記述的分析からは以下のようなことが指摘できる. 第 1 に, 日本でも専攻分 野が初職を明膫に水路づけている. 社会科学系出身者は男女ともに大企業 W や小 企業 W として入職する割合が多い一方で, 教育系や医療系出身者は専門職として 入職する割合が多い. 既存研究では見落とされてきたが, 実際には, 専攻分野もま た初職に大きく影響しているのである.

第 2 に, このような専攻分野がもたらす影響にはジェンダー差があることも確認 できる，人文系出身男性は専門職になりやすく $(39.1 \%)$, 同じ「文系」とされる 社会科学系出身者と比べても大企業に入職する割合が低い (31.3\%). それと比べ て人文系出身女性は専門職になりにくく $(25.2 \%)$, その分大企業に入職しやすい

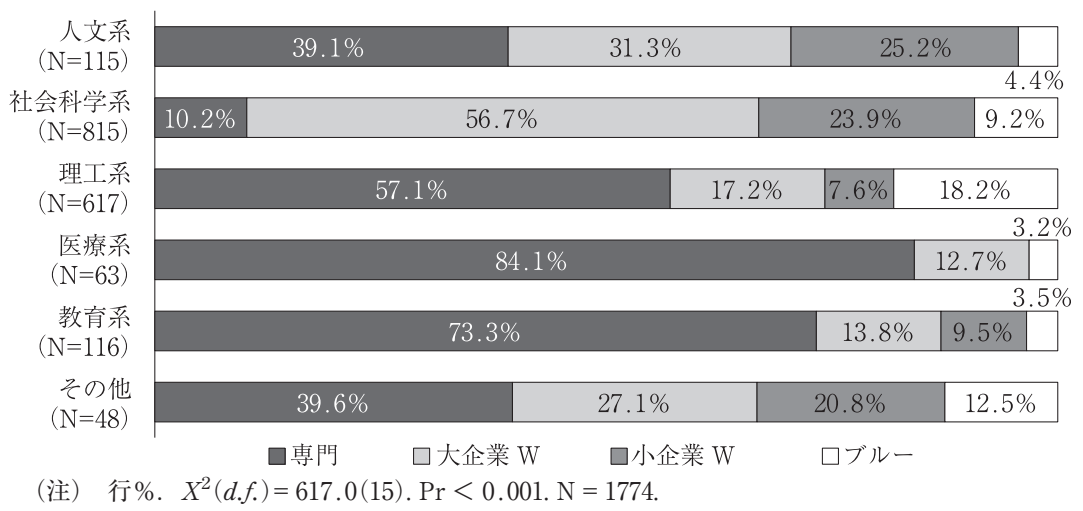

図 1 専攻分野別の初職の分布（大卒男性） 


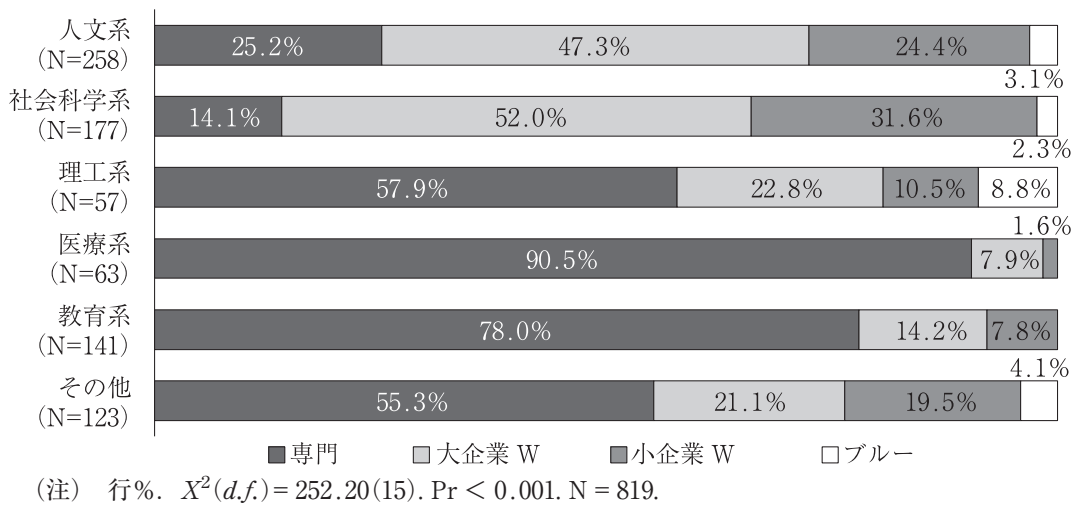

図 2 専攻分野別の初職の分布（大卒女性）

(47.3\%)。ささら，理工系出身男性は大企業 W にはなりにくい一方で $(17.2 \%)$, それと比べて理工系出身女性は大企業 W になりやすいといえる $(22.8 \%)$ 。このよ うに, 日本でも専攻分野が初職を明暸に水路づけていることはもちろん, 専攻分野 が初職にもたらす影響にはジェンダー差がある可能性が示唆される。こうしたジェ ンダー差について，性別と専攻分野の交互作用項から統計的検証を行う.

\section{2 学校歴と専攻分野の影響の男女比較分析}

以上のような記述的分析の結果を踏まえて，大卒男女の初職を従属変数にした多 項ロジスティック回帰分析の結果を表 2 に示す ${ }^{6)}$. 記述的分析から明らかであるが, 初職がブルーカラーの大卒者は極めて少ないため, 分析結果の掲載は省略した。 上 段は大企業 W を基準にして専門職に入職する場合であり，下段は小企業 W に入職 する場合の分析結果である.

上段左側の大卒男性の分析結果を確認する. Model 1 から, 大学に進学した後で も出身階層の影響は残存し, 父職地位が専門職であると大企業 Wよりも専門職に なりやすいことが確認できる。しかしながら学校歴を投入した Model 2 を確認する と, 大学院修了や学校歴は大企業 $\mathrm{W}$ と比べた専門職入職を大きく説明しているも のの ${ }^{7)}$, 父職専門職の回帰係数はほとんど減少していない $(1.097 \rightarrow 0.980)$. その 一方で専攻分野を投入した Model 3 を確認すると，父職専門職の回帰係数が大きく 減少していることに加えて $(0.980 \rightarrow 0.470)^{8)}$, Model 2 では確認された学校歴に よる影響がまったく確認できなくなった。このことは, 出身大学 (学校歴) という よりも出身学部 (専攻分野) が, 特定の職業で応用可能な能力のシグナルとして事 務販売職と比べた専門職入職に影響し，出身階層が初職にもたらす影響も大きく媒 介していることを意味している ${ }^{9)}$.

こうした結果を上段右側の大卒女性の結果と比較したい. Model 1 からは, 女性 の場合でも父職地位が専門職であると大企業 Wよりも専門職になりやすいことが 
表 2 初職の規定要因に関する男女比較分析（多項ロジスティック回帰分析）

\begin{tabular}{|c|c|c|c|c|c|c|c|c|c|c|c|c|}
\hline \multirow{3}{*}{ 専門 (基準 : 大企業W) } & \multicolumn{6}{|c|}{ 大卒男性 } & \multicolumn{6}{|c|}{ 大卒女性 } \\
\hline & \multicolumn{2}{|c|}{ Model 1} & \multicolumn{2}{|c|}{ Model 2} & \multicolumn{2}{|c|}{ Model 3} & \multicolumn{2}{|c|}{ Model 1} & \multicolumn{2}{|c|}{ Model 2} & \multicolumn{2}{|c|}{ Model 3} \\
\hline & Coef. & S.E. & Coef. & S.E. & Coef. & S.E. & Coef. & S.E. & Coef. & S.E. & Coef. & S.E. \\
\hline \multicolumn{13}{|l|}{ 父職地位 (基準：大企業W) } \\
\hline 専門 & $1.097^{\cdots *}$ & 0.230 & $0.980^{\cdots *}$ & 0.229 & $0.470^{*}$ & 0.231 & $0.854 *$ & 0.292 & $0.793 *$ & 0.293 & $0.626^{\circ}$ & 0.297 \\
\hline 小企業W & -0.403 & 0.263 & -0.252 & 0.262 & -0.332 & 0.263 & 0.416 & 0.365 & 0.470 & 0.365 & 0.589 & 0.366 \\
\hline 自営W & 0.535 & 0.296 & 0.530 & 0.297 & 0.280 & 0.296 & 0.120 & 0.430 & 0.126 & 0.429 & 0.100 & 0.431 \\
\hline 大企業B & -0.031 & 0.289 & -0.155 & 0.290 & -0.482 & 0.291 & 0.224 & 0.410 & 0.326 & 0.414 & 0.099 & 0.413 \\
\hline 小企業B & 0.474 & 0.310 & $0.627^{*}$ & 0.315 & 0.405 & 0.314 & 0.118 & 0.434 & 0.021 & 0.438 & 0.078 & 0.440 \\
\hline 自営B & 0.000 & 0.291 & -0.011 & 0.294 & -0.212 & 0.295 & 0.548 & 0.424 & 0.545 & 0.427 & 0.300 & 0.430 \\
\hline 農業 & 0.187 & 0.298 & 0.169 & 0.298 & -0.178 & 0.299 & $1.297^{*}$ & 0.572 & $1.253^{*}$ & 0.577 & 0.788 & 0.570 \\
\hline 無職+父不在 & 0.415 & 0.380 & 0.432 & 0.382 & 0.331 & 0.382 & 0.187 & 0.619 & 0.127 & 0.614 & 0.324 & 0.618 \\
\hline \multicolumn{13}{|l|}{ 学歴 (基準：学部卒業) } \\
\hline 大学院修了 & & & $1.487^{* *}$ & 0.256 & $0.719^{* *}$ & 0.258 & & & $1.312^{*}$ & 0.443 & $1.249^{*}$ & 0.449 \\
\hline \multicolumn{13}{|l|}{ 学校歷 (基準 : 私立大学 C 群) } \\
\hline 国公立大学A群 & & & $1.424^{* *}$ & 0.297 & 0.527 & 0.297 & & & $1.885 *$ & 0.669 & 0.473 & 0.672 \\
\hline 国公立大学B群 & & & $1.538^{* * *}$ & 0.231 & 0.132 & 0.243 & & & $1.602^{* *}$ & 0.381 & -0.054 & 0.417 \\
\hline 私立大学D群 & & & $0.583^{*}$ & 0.222 & 0.035 & 0.226 & & & 0.531 & 0.366 & -0.180 & 0.376 \\
\hline 私立大学E群 & & & $0.440^{\circ}$ & 0.232 & -0.023 & 0.236 & & & $1.108 *$ & 0.360 & 0.080 & 0.372 \\
\hline \multicolumn{13}{|l|}{ 専攻分野 (基準 : 社会科学) } \\
\hline 人文系専攻 & & & & & $1.838^{\cdots}$ & 0.259 & & & & & 0.438 & 0.296 \\
\hline 理工系専攻 & & & & & $2.672^{\cdots}$ & 0.180 & & & & & $1.792 \cdots$ & 0.433 \\
\hline 医療系専攻 & & & & & $3.316^{\cdots *}$ & 0.417 & & & & & $3.424 \cdots$ & 0.529 \\
\hline 教育系専攻 & & & & & $3.213^{* * *}$ & 0.322 & & & & & $2.660^{\cdots \cdots}$ & 0.381 \\
\hline その他専攻 (家政·芸術など) & & & & & $2.032^{* *}$ & 0.398 & & & & & $2.153^{\cdots *}$ & 0.351 \\
\hline \multicolumn{13}{|l|}{ 学校経由の就職 (基準：なし) } \\
\hline 学校経由あり & & & & & 0.122 & 0.142 & & & & & $0.526 *$ & 0.203 \\
\hline \multirow{3}{*}{ 小企業W (基準：大企業W) } & & & 大卒身 & & & & & & 大卒女 & & & \\
\hline & Model & & Mode & & Mode & 3 & Mode & & Model & 2 & Model & 13 \\
\hline & Coef. & S.E. & Coef. & S.E. & Coef. & S.E. & Coef. & S.E. & Coef. & S.E. & Coef. & $S . E$ \\
\hline 父職地位 (基準：大企業W) & & & & & & & & & & & & \\
\hline 専門 & -0.077 & 0.282 & -0.038 & 0.281 & 0.056 & 0.263 & 0.020 & 0.318 & -0.027 & 0.319 & -0.039 & 0.320 \\
\hline 小企業W & $0.834 *$ & 0.244 & $0.687^{*}$ & 0.246 & $0.736^{* *}$ & 0.243 & 0.693 & 0.363 & 0.640 & 0.362 & 0.629 & 0.364 \\
\hline 自営W & 0.469 & 0.309 & 0.392 & 0.307 & 0.485 & 0.303 & -0.037 & 0.458 & -0.154 & 0.462 & -0.140 & 0.462 \\
\hline 大企業B & 0.118 & 0.322 & 0.167 & 0.323 & 0.119 & 0.324 & -0.043 & 0.467 & -0.199 & 0.470 & -0.197 & 0.474 \\
\hline 小企業B & $0.778^{*}$ & 0.340 & 0.598 & 0.337 & 0.568 & 0.337 & 0.495 & 0.458 & 0.370 & 0.462 & 0.352 & 0.461 \\
\hline 自営B & 0.514 & 0.309 & 0.436 & 0.310 & 0.396 & 0.310 & 0.105 & 0.477 & 0.047 & 0.480 & 0.004 & 0.478 \\
\hline 農業 & -0.149 & 0.324 & -0.201 & 0.324 & -0.200 & 0.325 & 0.917 & 0.593 & 0.864 & 0.595 & 0.960 & 0.598 \\
\hline 無職+父不在 & 0.244 & 0.434 & 0.178 & 0.435 & 0.200 & 0.435 & 0.337 & 0.586 & 0.301 & 0.580 & 0.321 & 0.588 \\
\hline 学歴 (基準 : 学部卒業) & & & & & & & & & & & & \\
\hline 大学院修了 & & & -0.300 & 0.474 & -0.244 & 0.476 & & & -0.077 & 0.638 & -0.084 & 0.637 \\
\hline 学校歴 (基準：私立大学 $\mathrm{C}$ 君 & & & & & & & & & & & & \\
\hline 国公立大学A群 & & & $-1.215^{\circ}$ & 0.567 & -1.053 & 0.564 & & & 0.094 & 0.980 & 0.381 & 0.970 \\
\hline 国公立大学B群 & & & -0.442 & 0.323 & -0.477 & 0.324 & & & 0.533 & 0.451 & 0.699 & 0.469 \\
\hline 私立大学 D群 & & & $0.467^{*}$ & 0.220 & $0.488^{*}$ & 0.220 & & & 0.685 & 0.415 & 0.739 & 0.417 \\
\hline 私立大学 $\mathrm{E}$ 群 & & & $0.828^{* *}$ & 0.236 & $0.897^{* *}$ & 0.232 & & & $1.175^{* *}$ & 0.403 & $1.256^{*}$ & 0.406 \\
\hline 専攻分野 (基準: 社会科学) & & & & & & & & & & & & \\
\hline 人文系専攻 & & & & & $0.712^{* *}$ & 0.279 & & & & & -0.224 & 0.245 \\
\hline 理工系専攻 & & & & & 0.246 & 0.210 & & & & & -0.287 & 0.551 \\
\hline 医療系専攻 & & & & & -2.256 & 1.782 & & & & & -1.227 & 1.072 \\
\hline 教育系専攻 & & & & & 0.855 & 0.436 & & & & & -0.289 & 0.458 \\
\hline その他専攻 (家政·芸術など) & & & & & 0.591 & 0.458 & & & & & 0.210 & 0.345 \\
\hline 学校経由の就職 (基準：なし) & & & & & & & & & & & & \\
\hline 学校経由あり & & & & & $-0.454^{*}$ & 0.164 & & & & & -0.242 & 0.228 \\
\hline McFadden擬似決定倸数 & 0.04 & & 0.10 & & 0.20 & & & & 0.08 & & & \\
\hline -2Loglikelihood & 4603. & & 4302. & & 3796. & & 1931. & & 1859. & & 1626.9 & \\
\hline
\end{tabular}

（注） 1）男性： $\mathrm{N}=1865$. 女性 : $\mathrm{N}=884$. $^{* * *}: \mathrm{p}<0.001,{ }^{* *}: \mathrm{p}<0.01,{ }^{*}: \mathrm{p}<0.05$.

2) 切片, SSM 調査年ダミー, 入職コーホート, 初職時の居住地, 両親の学歴についての結果の掲載は省略した.

3）多重代入法による欠損值の補正を行った. 代入回数は 30 回, 分析に使用する変数すべてで予測した. 
わかる. 学校歴を投入した Model 2 では, 男性での結果と同様に大学院修了や学校 歴が大企業 $\mathrm{W}$ と比べた専門職入職を大きく説明しているものの, 父職専門職の回 帰係数はほとんど減少していない $(0.854 \rightarrow 0.793)$. それに対して専攻分野を投入 した Model 3 を確認すると, 男性ほどの大きさではないものの父職専門職の回帰係 数が減少していることに加えて $(0.793 \rightarrow 0.626)$, 学校歴による影響もまったく確 認できなくなった。しかしながら男性の結果とは異なり, 人文系と社会科学系出身 者の間には統計的に有意な差が確認できない上に, 理工系出身の回帰係数は男性よ りも小さいことが読み取れる（2.672 v.s. 1.792）。ジェンダー差の統計的検証は後 述するが, 男女ともに社会科学系よりも理工系・医療系・教育系出身者の方が事務 販売職と比べて専門職に入職しやすいことは確かであり, 専攻分野に関しては【仮 説 1】は支持され，【仮説 2】も支持されたといえる.

以上を踏まえて初職の企業規模の違いを検討した下段左側の大卒男性の結果を確 認する. Model 1 を確認すると, 父職の企業規模が小さい場合には大企業よりも小 企業に就職しやすいことがわかる. 学校歴を投入した Model 2 からは私立大学 C 群と比べて国公立大学 $\mathrm{A}$ 群では小企業には就職しにくい一方で, D 群や $\mathrm{E}$ 群では 反対に大企業よりも小企業に就職しやすいことが確認できる.こうした関連は専攻 分野とそれに伴う就職方法の違いを投入した Model 3 でもほとんど変化しないため, 出身大学は初職の企業規模を左右するといえる. その一方で尃攻分野の影響を確認 すると, 人文系出身者は同じ「文系」とされる社会科学系出身者と比べても大企業 より小企業に就職しやすいことがわかる．このことは，人文系出身であることがネ ガティブなシグナルとして機能していることを示唆している.

男女比較を行うために下段右側の大卒女性の Model 1 と Model 2 を確認すると, 女性の場合は出身階層の統計的に有意な影響が読み取れないが, 入試選抜度の低い $\mathrm{E}$ 群出身者が大企業よりも小企業に就職しやすい点は共通している．しかしながら Model 3 では, 男性の分析結果とは裏腹に, 人文系出身であることの統計的に有意 な影響が確認できない. このことは, 女性の場合には人文系と社会科学系出身者で 雇用主からの評価に大きな差がないことを示唆している．以上の男女比較分析から 明らかになったのは，理工系で多く利用される学校経由の就職が大企業（男性）や 専門職（女性）へのアクセスを高めていることは確かだが, それを考慮しても専攻 分野は男女ともに初職での専門職入職を左右しており, 出身階層の影響も大きく媒 介していることである，専攻分野も統制すると，学校歴は専門職入職というょりも 初職の企業規模を左右しており，【仮説 1】は全体的に支持されたといえる.

\section{3 男女比較分析の統計的検証}

専攻分野がもたらす影響のジェンダー差を統計的に検証するため, 全体サンプル を用いて Model 3 と同様のモデルに性別と専攻分野の交互作用項を投入した結果を 表 3 に示した．左側は大企業 W を基準にして専門職に入職する場合であり，右側 は小企業 W に入職する場合の分析結果である. なお, 紙幅の関係から主効果と交 
表 3 性別と専攻分野の交互作用項の検証

\begin{tabular}{|c|c|c|c|c|c|}
\hline \multirow{2}{*}{ （基準：大企業 W) } & \multicolumn{3}{|c|}{ 専門 } & \multicolumn{2}{|c|}{ 小企業 W } \\
\hline & Coef. & & S.E. & Coef. & S.E. \\
\hline \multicolumn{6}{|l|}{ 性別（基準：男性） } \\
\hline 女性 & 0.564 & * & 0.261 & 0.389 & 0.205 \\
\hline \multicolumn{6}{|l|}{ 専攻分野 (基準 : 社会科学) } \\
\hline 人文系専攻 & 1.845 & $* * *$ & 0.261 & $0.657^{*}$ & 0.271 \\
\hline 理工系専攻 & 2.651 & $* * *$ & 0.173 & 0.172 & 0.203 \\
\hline 医療系専攻 & 3.302 & $* * *$ & 0.416 & -2.090 & 1.533 \\
\hline 教育系専攻 & 3.192 & $* * *$ & 0.313 & 0.671 & 0.421 \\
\hline その他専攻 (家政·芸術など) & 2.069 & $* * *$ & 0.390 & 0.531 & 0.448 \\
\hline \multicolumn{6}{|l|}{ 交互作用項 (性別 $\times$ 専攻分野) } \\
\hline 女性 $\times$ 人文系専攻 & -1.299 & $* * *$ & 0.380 & $-0.902^{*}$ & 0.359 \\
\hline 女性 ×理工系専攻 & -0.908 & $*$ & 0.433 & -0.373 & 0.547 \\
\hline 女性 $\times$ 医療系専攻 & 0.145 & & 0.657 & 1.013 & 1.857 \\
\hline 女性×教育系専攻 & -0.508 & & 0.455 & -0.729 & 0.595 \\
\hline 女性×その他専攻 & 0.073 & & 0.503 & -0.308 & 0.555 \\
\hline McFadden 擬似決定係数 & \multicolumn{5}{|c|}{$\begin{array}{c}0.199 \\
5529.608\end{array}$} \\
\hline
\end{tabular}

（注） 1） $\mathrm{N}=2749$. $^{* * *}: \mathrm{p}<0.001,{ }^{* *}: \mathrm{p}<0.01,^{*}: \mathrm{p}<0.05$.

2）主効果と交互作用項の結果のみ揭載している.

3）表 2 と同様に, 多重代入法による欠損值の補正を行った.

互作用項の結果のみ掲載している.

女性と人文系専攻の交互作用項から確認する. 左側を確認すると交互作用項は統 計的に有意であり，人文系出身男性は大企業 Wよりも専門職になりやすいのに対 して (1.845), それと同程度に人文系出身女性が大企業 Wよりも専門職になりや すいわけではない $(1.845-1.299=0.546)$. 人文系出身男性は大企業よりも小企業 に就職しやすいが $(0.657)$, それと同様に人文系出身女性が小企業に就職しやすい わけでもない $(0.657-0.902=-0.245)$. 以上から, 同じ人文系出身であっても女 性は男性と同様に小企業に就職しやすいわけではなく, 人文系出身であることがネ ガティブなシグナルとして機能することは確かだが，それは男性に限定的で女性に はあてはまらないことが明らかになった，以上から【仮説 3a】は支持され，女性 の場合には専攻分野にこだわらない採用が行われている可能性が示唆された.

最後に女性と理工系専攻の交互作用項を確認したい。左側を確認すると交互作用 項は統計的に有意であり，理工系出身男性は大企業 Wより専門職になりやすいも のの (2.651), それと同程度に理工系出身女性が大企業 Wよりも専門職になりや すいわけではない $(2.651-0.908=1.743)$. その一方で, 右側の交互作用項は統計 的に有意ではなく, 初職の企業規模に関しては統計的に有意なジェンダー差が確認 できない。こうした結果は【仮説 3b】を支持しており，理工系の進路選択だけで なく，理工系専攻が初職にもたらす影響にもジェンダー差があることが明らかにな った．理工系では男女間の職域分離が大きく，同じ理工系出身でも女性は男性ほど 事務販売職と比べて専門職になりやすいわけではないといえる10). 


\section{5 結 論}

本稿では, 出身大学の学校歴と専攻分野が初職にもたらす影響の男女比較分析を 行った，従来の研究では十分に考慮されてこなかった専攻分野，出身階層，大卒女 性も含めた分析を行った結果，学校歷は訓練可能性を示す能力のシグナルとして企 業規模を左右する一方で，専攻分野もまた職場で応用可能な能力のシグナルとして 機能することが示された．男女ともに入試選抜度の高い大学出身者ほど初職の企業 規模が大きく，教育内容の専門性が高い理工系・医療系・教育系出身者ほど，大企 業 Wよりも専門職になりやすかった【仮説 1】。こうした初職への影響から, 教育 選抜に基づく学校歴ではなく，教育選択に基づく専攻分野が出身階層の影響を大き く媒介しており，男女ともに父職地位が尃門職の場合には理工系や教育系などの専 門職への入職が見通しやすい専攻分野を選択しやすいために，大企業 Wよりも専 門職になりやすい【仮説 2】.さらに労働市場が男女で分断されているため, 人文 系出身者の初職での不利は男性に限定的である一方で【仮説 3a】, 同じ理工系出身 でも女性は男性ほど事務販売職と比べて専門職になりやすいわけではなかった【仮 説 $3 \mathrm{~b}$ 】.

学歴がキャリアにもたらす影響には出身校による学校効果（school effect）と教 育内容による専門効果（study programme effect）の 2 つがあり，後者を無視する ことは学歴がもたらす効果全体の過小評価につながると指摘されている（van der Velden \& Wolbers 2007). 重要なことは, 日本社会でも専攻分野による専門効果が 無視しえない役割を果たしており，一見すると自由な教育選択による「専攻間卜ラ ッキング」によっても初職は明膫に水路づけられているということである ${ }^{11)}$. 出 身大学の学校歴は初職を全面的に左右するわけでなく, 専攻分野も考慮するとあく までも企業規模に大きく影響する限定性があった，その一方で初職入職経路が尃門 職か事務販売職かの違いは, 出身大学 (学校歴) というよりも出身学部 (専攻分 野）によってほとんど説明された。こうした結果を踏まえれば, 既存研究は学校歴 がもたらす学校効果を過大評価する一方で，専門効果を含む学歷がキャリアにもた らす効果全体を過小評価してきたと考えられる12).

また本稿の分析結果は, 日本の文脈でも専攻分野選択のメカニズムを検討する必 要性を示唆している. 欧米諸国では将来的な職業達成を見通した専攻分野選択と出 身階層の関連が多く議論されてきた（Kraaykamp et al. 2013 など）．日本の高校生 たちがどの程度まで将来的な職業達成を考えて専攻分野を選択しているのかは必ず しも明らかではないものの, 本稿の分析では父職地位が尃門職の場合に本人もまた 専門職になりやすいことは, 出身大学というょりも専攻分野選択によって大きく説 明されている，近年では普通科高校の多くで文理選択が導入されており，その後の 進路選択を大きく水路づけている現状を踏まえれば（河野 2009）, 初職を水路づけ る「専攻間トラッキング」の前段階として専攻分野がどのように選択されているの 
かを明らかにする必要がある。

さらに, 既存研究が議論してきた専攻分野選択だけではなく, 専攻分野が初職に もたらす影響にもジェンダー差があることを示した本稿の議論は男女間格差に関す る議論に対しても大きな意味をもつ. 同じ理工系出身でも女性は男性ほど事務販売 職と比べて専門職になりやすいわけではない一方で, 男性に対してのみ人文系出身 であることがネガティブなシグナルとして機能することが示された. このことは， 男性向き進路とされる理工系を選択した女性や, そうした男性向き進路をはずれた 人文系出身男性に対して, 雇用主がネガティブな評価を行っている可能性も示唆し ている. 進路選択段階でのジェンダー差だけではなく, 労働市場での評価のジェン ダー差についても議論することが新たな課題となるだろう.

ただし，本稿の知見には学校歴や専攻分野が初職に与える影響を検討したに過ぎ ないという限界がある. 初職入職後のキャリアで学校歴や専攻分野がどのような役 割を果たしているのかは明らかではなく, キャリア後半でも学校歴や専攻分野のこ うした影響は持続するのかを検証することが今後の研究には求められる.

[付記］本稿は，2016 年度に提出した東京大学大学院教育学研究科修士学位論文「大卒学歴内部 の不平等はなぜ生まれるか一専攻間格差の計量社会学」の一部を大幅に改稿したものである. JSPS 科研費特別推進研究事業（課題番号 25000001）に伴う成果の 1つであり, SSM1995 年, 2005 年, 2015 年 $(2017$ 年 2 月 27 日版 : バージョン 070) 調查データの使用にあたっては 2015 年 SSM 調查デー夕管理委員会の許可を得た.

匿名の 2 名の查読者の先生方, および, 中村高康先生, 佐藤香先生, 須藤康介先生, 小川和孝先 生, 山口泰史さん, 胡中孟徳さん, 麦山亮太さん, 打越文弥さんからいただいたコメントは本稿の 改善にとってなくてはならないものであった，記して感謝申し上げる.

\section{[注]}

1）平成 29 年の過年度高卒者等も含む 4 年制大学進学率を指す.

2）数少ない例外としては, 平沢和司（2010）が学校歴と企業規模の関連を議論しているが, 代 表性のある調査デー夕を用いた実証研究は十分に蓄積されていないのが現状である.

3）もちろん彼らの議論の力点は, イギリスでは学業成績の方が大きく重視されるなど, 雇用主 の評価には国家間の違いがあるという点にある. ただし程度の差はあるものの, 専攻分野もま た評価の対象になっていること自体は日本も含めて共通しているだろう。

4） 1995 年調査は 1994 年 12 月末時点で満 20 69 歳の男女, 2005 年調查は 2005 年 9 月末時点 で満 20 69 歳の男女, 2015 年調査は 2014 年 12 月末時点で満 20 79歳の男女を対象に行われ た訪問面接調査である. 回収率は, 1995 年調査が $65.8 \%, 2005$ 年調査が $44.1 \%, 2015$ 年調査 が $50.1 \%$ である.

5） 入試偏差值は各年度の志願率によって変動する問題があるため, 設置時期に着目した大学類 型を使用した，設置時期の古い大学ほど入試選抜度も高い傾向にある（金子 1996）。

6）ロジットモデルなどの非線形モデルは線形モデルのように追加変数による回帰係数の変動を 単純に比較できないため, そうした問題に対応するために提案されている KHB method を使用 した (Karlson et al. 2012). そのため, 縮小モデルには残差得点も投入しているが回帰係数の 揭載は省略した。またモデル適合度はすべてのモデルでフルモデル（Model 3）と同一になる 
が, 結果を読み取りやすくするため, 縮小モデルには KHB method で調整しない場合のモデル 適合度も報告した。

7）国公立大学には医療系・教員養成系学部が，D 群や E 群には理工系単科大学などが多く含ま れるため, C 群と比べると大企業 Wよりも専門職になりやすいと考えられる.

8）本稿ではサンプルサイズの限界から, Delta-methodによる間接効果の標準誤差算出と検定で はなく, 媒介の大きさ（回帰倸数の変動）から間接効果を議論した.

9）学校経由の就職を統制しない場合や，従属変数の基準カテゴリーを小企業Wに変えた場合に も結果はほとんど変わらないことを確認している. 初職が尃門職か事務販売職かの違いは, 就 職方法の違いによらず専攻分野によって水路づけられているといえる.

10）同じ「理工系」でも，男性は電気・機械系を，女性は数学・生物系を選択しやすく，そうし た学科単位のジェンダー差も加わって, 理工系女性は専門職よりも大企業Wになりやすく, 理 工系進路で男女間職域分離が大きいことも推測される.

11）本稿では「専攻間トラッキング」を高校生段階での文理選択や専攻分野選択を含んだ広い意 味で用いており, 実際には複線型の学校教育システムではなくても, 一見すると自由な専攻分 野選択によって初職が大筋で水路づけられている状沉に言及している.

12）擬似決定係数であるためあくまで参考程度であるものの, 現に表 2 で学校歴を投入した Model 2 の擬似決定係数は 0.103 (男性), 0.087 (女性) であるのに対して, 専攻分野も投入 した Model 3 では 0.208 (男性), 0.201 (女性) にまで上昇している.

\section{[文献]}

天野郁夫, 2006, 『教育と選抜の社会史』筑摩書房.

Di Stasio, V. \& H. G. van de Werfhorst, 2016, “Why Does Education Matter to Employers in Different Institutional Contexts? A Vignette Study in England and the Netherlands," Social Forces, 95 (1) : 77-106.

Fujihara, S. \& H. Ishida, 2016, “The Absolute and Relative Values of Education and the Inequality of Educational Opportunity: Trends in Access to Education in Postwar Japan," Research in Social Stratification and Mobility, 43: 25-37.

古田和久, 2016, 「学業的自己概念の形成におけるジェンダーと学校環境の影響」『教育学研究』 83 (1) : 13-25.

Gerber, T. P. \& S. Y. Cheung, 2008, “Horizontal Stratification in Postsecondary Education: Forms, Explanations, and Implications," Annual Review of Sociology, 34: 299-318.

平沢和司, 2010,「大卒就職機会に関する諸仮説の検討」苅谷剛彦・本田由紀編『大卒就職の社会 学——゙ータからみる変化』東京大学出版会, 61-85.

, 2011,「大学の学校歴を加味した教育・職業達成分析」石田浩・近藤博之・中尾啓子編

『現代の階層社会 2 階層と移動の構造』東京大学出版会, 155-70.

石田浩, 2005, 「後期青年期と階層・労働市場」『教育社会学研究』76: 41-57.

石田賢示, 2014, 「学校から職業への移行における『制度的連結』効果の再検討一一初職離職リス クに関する趨勢分析」『教育社会学研究』94: 325-44.

Kalmijn, M. \& T. van der Lippe, 1997, “Type of Schooling and Sex Differences in Earnings in the

Netherlands," European Sociological Review, 13: 1-15.

金子元久，1996,「高等教育大䍃化の担い手」天野郁夫・吉本圭一編『学習社会におけるマス高等 教育の構造と機能に関する研究』放送教育開発センター, 37-59. 
Karlson, K. B., A. Holm \& R. Breen, 2012, “Comparing Regression Coefficients Between Samesample Nested Models Using Logit and Probit: A New Method," Sociological Methodology, 42: 286-313.

河野銀子，2009，「女子高校生の『文』『理』選択の実態と課題」『科学技術社会論研究』7:21-33. 胡中孟德，2015，「社会移動における専攻分野の位置づけの検討一大学での専攻分野に着目して」 中村高康編『全国無作為抽出調査による「教育体験と社会階層の関連性」に関する実証的研 究』2011-14 年度科学研究費補助金研究成果報告書, 教育・社会階層・社会移動調查研究会, $184-95$.

Kraaykamp, G., J. Tolsma \& M. H. J. Wolbers, 2013, “Educational Expansion and Field of Study: Trends in the Intergenerational Transmission of Educational Inequality in the Netherlands," British Journal of Sociology of Education, 34: 888-906.

Lucas, S. R., 2017, “An Archaeology of Effectively Maintained Inequality Theory," American Behavioral Scientist, 61(1): 8-29.

文部科学省, 2017, 『学校基本調査』(2018 年 6 月 27 日取得, http://www.mext.go.jp/b_menu/ toukei/chousa01/kihon/1267995.htm).

尾嶋史章, 1990, 「教育機会の赹勢」菊池城司編『現代日本の階層構造 3 教育と社会移動』東京大 学出版会, 25-55.

Ortiz, L. \& J. Rodriguez-Menés, 2016, “The Positional Value of Education and its Effect on General and Technical Fields of Education: Educational Expansion and Occupational Returns to Education in Spain," European Sociological Review, 32(2) : 216-37.

Reimer, D., C. Noelke \& A. Kucel, 2008, "Labor Market Effects of Field of Study in Comparative Perspective: An Analysis of 22 European Countries," International Journal of Comparative Sociology, 49(41-5) : 233-56.

Shauman, K. A., 2006, "Occupational Sex Segregation and the Earnings of Occupations: What Causes the Link Among College-Educated Workers?," Social Science Research, 35 (3): 577-619.

白川俊之, 2015, 「大学・短大の専門分野はどのように決まるのか一出身階層と高等教育の学科 · 専攻との関係」中澤渉・藤原翔編『格差社会の中の高校生—家族・学校・進路選択』勁草書 房, 53-67.

高松里江, 2008, 「非正規雇用の規定要因としての高等教育専攻分野一一水平的性別専攻分離の職 域分離への転化に着目して」『年報人間科学』29(2): 75-89.

—，2014，「進路選択に抒けるジェンダー・トラック——男女間・女子内の文化に着目して」 『2013 年度課題公募型二次分析研究会 高校生の進路意識の形成とその母親の教育的態度との関 連性研究成果報告書』東京大学社会科学研究所附属社会調查データアーカイブ研究センター, 75-90.

竹内洋, 1995, 『日本のメリトクラシー——構造と心性』東京大学出版会.

van der Velden, R. \& M. Wolbers, 2007, “How Much Does Education Matter and Why?: The Effects of Education on Socio-economic Outcomes among School-leavers in the Netherlands," European Sociological Review, 23(1): 65-80.

van de Werfhorst, H. G. \& R. Luijkx, 2010, “Educational Field of Study and Social Mobility: Disaggregating Social Origin and Education," Sociology, 44: 695-715. 山口一男, 2017, 『働き方の男女不平等一一理論と実証分析』日本経済新聞出版社. 
山本耕平 ·安井大輔, 2016, 「大卒女性における専攻間賃金格差の分析一一理工系出身女性の賃金 抑制要因に着目して」『ソシオロジ』61(1): 63-81.

（原稿受付 2017.6.17 掲載決定 2018.6.27) 


\title{
Effects of College Selectivity and College Major on First Job Attainment among Male and Female University Graduates:
}

\author{
Limited Scope of College Selectivity Effects and Tracking between College \\ Majors
}

\author{
TOYONAGA, Kohei \\ Graduate School of Education, \\ The University of Tokyo; JSPS Research Fellow
}

kohei.toyonaga@gmail.com

In this paper, I examine the effects of the degree of college selectivity in terms of admission and college major on first job attainment, paying attention to the different experiences of men and women. Through better access to higher education, relative disparity within college educational attainment has increased. In this context, previous research has focused on the effect of college selectivity, while overlooking the effect of college major or social background. In addition, researchers did not examine the experiences of women. Using integrated SSM data from 1995, 2005, and 2015, I focus on college major and social background, paying attention to women with four-year university degrees. Results of the analysis revealed three points. First, while college selectivity affected company size as a signal of trainability, college major is seen as a signal of application potential for professionals. Second, the effect of social background on the first job is mediated by college major, rather than by college selectivity. Therefore, college major choice with regard to future job aspiration plays an important role in explaining intergenerational mobility in Japan. Third, there is a gender difference in the effect of college major on the first job. For large companies, men who graduate from the humanities suffer from a negative evaluation from potential employers, while women do not. In contrast, when considering professional jobs for graduates of the STEM fields, women are less likely to be hired compared to their male counterparts—even when graduating with the same major. To summarize, this study shows that college selectivity has a limited scope in determining company size of graduates' first jobs. It also shows that differences between college majors plays an important role depending on social status and gender.

Key words: college selectivity, college major, first job attainment

(Received Jun. 17, 2017 / Accepted Jun. 27, 2018)

69 (2) 178 